\title{
Analisis kompetensi pedagogik guru PAI dalam mengimplementasikan kurikulum di SMA Negeri
}

\author{
Maya Safitri a,1,* \\ a Institut Agama Islam Negeri Lhoksumawe, Jl. Medan-Banda Aceh, Lhokseumawe, Aceh 24352, Indonesia \\ 1 mayasafitri2007@gmail.com \\ * corresponding author
}

\section{ARTICLE INFO}

\section{Article History}

Received: 03 of January, 2021

Revised: 30 of January 2021

Accepted: 31 of January 2021

Keyword: Pedagogical competencies, Curriculum implementation, Teacher PAI

Kata Kunci: Kompetensi pedagogik, Impelementasi kurikulum, Guru PAI

\begin{abstract}
Pedagogical competence has a very important role in implementing the curriculum. Managing pedagogical competencies is a common problem in realizing learning objectives. The purpose of this study is to describe the pedagogical competence of PAI teachers, the efforts and constraints of PAI teachers in implementing curriculum in five state high schools in Aceh. This research uses descriptive qualitative research methods, data collection techniques through, observation, indepth interviews, and documentation. The results showed that the pedagogical competence of PAI teachers is well managed which is realized by the preparation of learning plans, syllabus, annual programs, and semester programs. The competency development effort is carried out through training, self-development, supervision, motivation, and teacher training activities. While the constraints of curriculum implementation are lack of motivation, weak mastery of technology and information, lack of socialization of curriculum changes and evaluation of learning, limited learning resources, minimal curriculum structure allocation, and low student input.
\end{abstract}

\section{ABSTRAK}

Kompetensi pedagogik guru PAI memiliki peran yang sangat penting dalam mengimplementasikan kurikulum. Pengelolaan kompetensi pedagogik menjadi problem yang umum ditemui dalam mewujudkan tujuan pembelajaran. Tujuan penelitian ini adalah untuk mendeskripsikan kompetensi pedagogik guru PAI, upaya dan kendala guru PAI dalam mengimplementasikan kurikulum pada lima SMA Negeri di Aceh. Penelitian yang dilakukan menggunakan metode penelitian kualitatif deskriptif, teknik pengumpulan data dilakukan dengan observasi, wawancara mendalam, dan dokumentasi. Hasil penelitian memberikan deskripsi kompetensi pedagogik guru PAI dikelola dengan baik yang diwujudkan dengan penyusunan rencana pembelajaran, silabus, program tahunan, dan program semester, pelaksanaan pembelajaran, dan evaluasi pembelajaran. Upaya pengembangan kompetensi dilakukan dengan kegiatan pelatihan, pengembangan diri, supervisi, motivasi, dan pembinaan guru. Sedangkan kendala implementasi kurikulum adalah kurangnya motivasi, lemahnya penguasaan teknologi dan informasi, minimnya sosialisasi perubahan kurikulum dan evaluasi pembelajaran, terbatasnya sumber belajar, alokasi struktur kurikulum yang minim, dan input peserta didik yang rendah.

This is an open access article under the CC-BY-SA license.

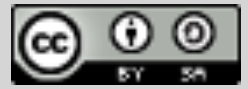




\section{Pendahuluan}

Kurikulum memiliki substansi yang sangat penting dalam pengelolaan pendidikan nasional. Pembangunan sumber daya manusia yang berkualitas sangat dipengaruhi oleh ketersediaan dan keterlaksanaan rencana pendidikan yang terpadu dan terukur. Kurikulum merupakan instrument yang digunakan dan dikembangkan dalam pengelolaan tingkat satuan pendidikan. Instrumen ini disusun dengan penuh perhatian dan pertimbangan terhadap kebutuhan masyarakat di masa yang akan datang, kebutuhan sumber daya secara nasional, perkembangan ilmu pengetahuan dan teknologi, seni, serta tantangan dan tuntutan kompetensi yang dibutuhkan oleh para peserta didik pada masa yang akan datang.

Pendidikan saat ini mengalami perkembangan yang sangat signifikan, ditandai dengan berkembangnya ilmu pengetahuan, teknologi, meluasnya media informasi berbasis cloud dari berbagai sumber dan berbagai lokasi baik lokal, regional, dan global. Globalisasi menjadi suatu hal yang lumrah dan biasa, suatu momentum kejadian di suatu tempat berdampak dan berimplikasi pada keputusan-keputusan pada orang-orang di tempat yang lain. Ada kekhawatiran tentang budaya, nilai-nilai esensial, karakter, yang bergeser dan tergerus dengan logika-logika yang hedonis dan pragmatis. Demikian itu sebagaimana disampaikan oleh Tilaar (2003) yang mengemukakan bahwa perubahan pada masyarakat dipengaruhi oleh tiga faktor utama yaitu; perkembangan ilmu pengetahuan dan teknologi, keterlibatan masyarakat dalam berbagai pengambilan kebijakan (upaya demokratisasi), dan dorongan globalisasi [1].

Menanggapi hal tersebut, sistem pendidikan dan pengembangan kurikulum menjadi hal yang mutlak untuk berevolusi dan diperbaharui. Model pendidikan kontekstual menjadi pilihan yang dibutuhkan pada proses pembelajaran, pendekatan pembelajaran yang demokratis menjadi hal yang dituntut implementasinya. Pemerintah menerbitkan peraturan perundang-undangann Nomor 20 tahun 2003 tentang Sistem Pendidikan Nasional, kemudian diturunkan dalam Peraturan Pemerintah No. 19 tahun 2005 tentang Standar Nasional Pendidikan, yang menghasilkan Kurikulum 2004 dengan konsep pembelajaran demokratis atau dikenal dengan democratic learning. Dua tahun berselang, kurikulum dikembangkan menjadi Kurikulum 2006 yang dikenal dengan Kurikulum Tingkat Satuan Pendidikan (KTSP) dengan asumsi konsep differencial competency teaching, sebagai upaya desentralisasi pendidikan dan otonomi pada tingkat satuan pendidikan. Desain kurikulum yang demikian itu menunjukkan upaya yang dilakukan oleh pemerintah dalam mewujudkan tujuan pendidikan nasional.

Pencapaian tujuan nasional melalui kurikulum yang telah disusun, membutuhkan pemahaman guru yang komprehensif dan mendalam terkait struktur kurikulum, esensi dan substansi dari kurikulum, pola-pola perencanaan pembelajaran, pelaksanaan pembelajaran, dan evaluasi pembelajaran yang relevan dengan kurikulum. Pengembangan kurikulum sesuai dengan arahan pemerintah menjadi suatu keharusan dalam menghadapi perubahan dan tantangan internal dan eksternal. Tantangan internal yaitu upaya penguatan terhadap 8 standar nasional yang dicanangkan oleh pemerintah, Adapun tantangan eksternal adalah ketersediaan sumber daya manusia yang menjawab kebutuhan masyarakat yang akan datang terkait kompetensi, persepsi masyarakat, perkembangan pengetahuan, pendidikan dan pedagogik, dan fenomena-fenomena unik di masyarakat. Perubahan tersebut meliputi bebagai hal yaitu kompetensi lulusan, proses pembelajaran, isi kurikulum, dan penilaian pendidikan. Mulyasa (2014) mengungkapkan suatu penekanan pada kompetensi lulusan yang mencakup tiga domain utama yaitu sikap, keterampilan, dan pengetahuan. Mata pelajaran yang dikembangkan, juga diharuskan agar sesuai dengan perencanaan, pelaksanaan, dan evaluasi pembelajaran [2].

Temuan uji publik tentang implementasi Kurikulum 2013 menunjukkan bahwa $71 \%$ responden menyatakan setuju dengan justifikasi dan SKL dalam Kurikulum 2013 dan 81 \% responden menyetujui persiapan guru-guru dalam mengimplementasikan kurikulum tersebut. Demikian itu menunjukkan bahwa perubahan kurikulum dapat diterima oleh guru-guru, dan guru-guru mempersiapkan diri dan menerima perubahan. Hanya sebagian lain dari guru-guru yang ragu-ragu dan menolak perubahan. Informasi ini menjadi penting, mengingat guru memegang peranan yang penting dalam pengelolaan kurikulum. Keberhasilan mewujudkan tujuan kurikulum sangat bergantung pada guru yang memiliki kemampuan dan keterampilan. 
Tidak dapat dipungkiri bahwa keberhasilan kurikulum sangat dipengaruhi oleh dua faktor utama, yaitu faktor kompetensi pendidik terhadap implementasi kurikulum, administrasi pembelajaran, dan implementasi pembelajar, dan faktor pendukung proses pembelajaran. Pendukung proses pembelajaran meliputi bahan ajar dan sumber belajar, penguatan pemerintah terhadap pembinaan dan pengembangan guru dalam hal ini adalah aspek penilaian dan pengawasan, dan pengelolaan sekolah dan madrasah dalam aspek manajemen dan budaya sekolah. Kurikulum 2013 menuntut guru untuk melaksanakan pembelajaran dengan struktur tematik integratif, oleh karena itu guru diharapkan memiliki kompetensi professional yang utama, tetampi juga dibutuhkan optimalisasi terkait kompetensi pedagogik, kompetensi sosial, dan kompetensi kepribadian.

Terkait dengan kompetensi pedagogik menjadi hal yang sangat dibutuhkan mengingat pendekatan pembelajaran yang demokratis. Guru diharapkan memiliki pemahaman dan pengetahuan yang baik terhadap peserta didik, karakter dan tingkah lakunya. Pengetahuan tentang karakter, dan upaya memahami karakter peserta didik berimplikasi pada proses pembelajaran yang mendorong peserta didik agar terbentuk kompetensi sikap yang diharapkan. Pendekatan pembelajaran scientific learning approach merupakan pendekatan yang didasari oleh pola komunikasi, tetapi juga optimalisasi dapat dilakukan melalui media pembelajaran yang baik, dipersiapkan, dan menarik. Kompetensi guru dikembangkan pada penguasaan pembelajaran yang membahagiakan, menginspirasi, memberikan motivasi, dan memberikan keluasaan kepada peserta didik untuk mengembangkan bakat dan potensinya melalui kegiatan-kegiatan observasi, inquiri, menggali gagasan, merefleksi, dan membuat kesimpulan.

Ismail (2015) mengungkapkan kebutuhan akan kompetensi pedagogik bagi guru PAI yang harus diperhatikan oleh pengelola lembag pendidikan Islam, pemerintah, dan masyarakat. Dengan harapan guru dapat membentuk peserta didik yang berkarakter, berakhlaq mulia, berbudi pekerti luhur, berkepribadian yang unggul, dan bermartabat [3]. Senada dengan hal tersebut Mulyadi (2011) mengungkapkan bahwa kompetensi pedagogik guru berkontribusi terhadap kinerja guru PAI, demikian itu dibuktikan dengan hitungan regresi sebesar 6, 76 \% [4]. Kosim (2016) mengemukakan temuannya bahwa kualitas pembelajaran PAI yang dalam hal ini disebut dengan mutu pembelajaran sangat dipengaruhi oleh kompetensi pedagogik, disebutkan bahwa kontribusi pengaruh tersebut adalah sebesar 74, $5 \%$, yang berarti kontribusi yang tinggi [5].

Selain berkontribusi terhadap kinerja guru, dan mutu pembelajaran, kompetensi pedagogik juga berpengaruh terhadap peserta didik. Penelitian yang dilakukan Indra (2016) menunjukkan bahwa kompetensi pedagogik bersama dengan kompetensi professional berpengaruh terhadap prestasi belajar peserta didik.[6] Senada dengan temuan Indra (2016), Umami dan Roesminingsih (2014) mengunkapkan bahwa kompetensi pedagogic berpengaruh terhadap prestasi belajar sebesar $15,9 \%$ [7]. Rizqi, Affandi, dan Nuryadien (2019) motivasi belajar peserta didik dipengaruhi oleh kompetensi pedagogik yaitu sebesar 25, 8 \% [8]. Abdillah (2015) mengemukakan bahwa kompetensi professional dan kompetensi pedagogik berpengaruh terhadap evaluasi pembelajaran PAI di SMA, disebutkan bahwa hasil koefisien determinan regresi yaitu sebesar 50,3\% [9].

Temuan penelitian yang dilakukan oleh Habibullah (2012) terkait dengan kompetensi pedagogik guru madrasah di Jawa Tengah secara umum dalam kategori kurang dan sangat kurang, hanya aspek menyusun rencana pembelajaran dan aspke pelaksanaan pembelajaran dalam kategori cukup [10]. Munajat (2016) mengemukakan faktor-faktor yang menghambat penguasaan kompetensi pedagogik guru yaitu; minimnya penatarak Kurikulum 2013, belum tersedianya sarana pembelajaran LCD proyektor di sekolah, kurangnya pembinaan KKG dan MGMP, dan kegiatan PLPG yang relative singkat [11].

Guru menjadi tumpuan harapan masyarakat dan bangsa untuk mendidik anak-anak generasi yanga akan datang agar menjadi generasi yang berkarakter mulia, dan sukses dalam kehidupan. Guru tidak dibebani tanggungjawab pembelajaran pada penyampaian pesan pembelajaran pada peserta didik, tetapi juga mempersiapkan mereka bersamaan dengan seluruh karakter kepribadiannya yang baik, posistif dan produktif, agar siap menghadapi kehidupan yang penuh dengan tantangan. Tenaga pendidik sebagaimana dalam peraturan perundang-undangan disebutkan tugas yang menjadi kewajibannya yaitu melaksankan tugas administrasi pendidikan, pengelolaan pembelajaran, pengembangan pembelajaran, pengawasan pembelajaran dan pelayanan teknis untuk menunjang proses pendidikan pada satuan pendidikan [12]. Sikap Guru yang responsif terhadap pembaharuan dan perkembangan ilmu pengetahuan dan teknologi merupakan suatu keharusan. 
Selain daripada itu, guru diharapkan untuk meningkatkan pengetahuan yang dimiliki, kualitas pendidikan yang telah dimiliki, dan kualitas diri. Sehingga berdampak pada proses pendidikan dan pembelajaran yaitu pembelajaran menjadi leibh kreatif, aktif, dan menyenangkan bagi guru dan peserta didik.

Hasil Uji Kompetensi Guru (UKG) yang diselenggarakan pada tahun 2012 menunjukkan bahwa dominan guru mendapatkan nilai di bawah rata-rata nasional. Temuan data menunjukkan, terdapat guru bersertifikasi mendapatkan nilai 40 dari nilai maksimal sebesar 91. Data ini menunjukkan bahwa secara umum para guru dalam kategori rendah pada aspek kompetensi yang menjadi keharusan. Empat kompetensi guru memiliki tujuan agar para peserta didik mendapatkan quality assurance dari tenaga pendidik dalam mengembangkan pembelajaran [13]. Kompetensi guru sangat perlu dalam mengimplemantasikan kurikulum, mengingat bahwa kompetensi memiliki hubungan dengan tindakan pengembangan kurikulum dari mulai perencanaan, pengorganisasian, impelementasi proses pembelajaran yang dilakukan di dalam kelas, dan evaluasi kurikulum.

Fokus penelitian kompetensi pedagogik pada penelitian ini adalah kemampuan guru dalam mengelola dan mengembangkan proses pembelajaran yang terdiri dari pemahaman terhadap peserta didik, perencanaan pembelajaran, implementasi pembelajaran, evaluasi hasil belajar dan mengaktualisasikan bakat dan potensi peserta didik pada guru PAI. Kompetensi pedagogik yang menjadi dasar penelitian ini adalah berdasarakan Permendiknas Nomor 16 Tahun 2007 tentang standar kualifikasi akademik dan kompetensi guru. Kompetensi pedagogik guru sangat dibutuhkan untuk untuk diketahui oleh para pengelola dan pengambil kebijakan. Kompetensi ini dikaitkan dengan implementasi kurikulum PAI pada tingkat SMA. Pengetahuan tentang kompetensi pedagogik guru dapat dijadikan sebagai analisis untuk pengembangan kompetensi tersebut, dan kompetensi-kompetensi yang lain yang terkait dengannya.

Berdasarkan paparan yang telah disampaikan, penelitian ini memberikan manfaat kepada para pendidik dan pemangku kebijakan tentang pencapaian kompetensi pedagogik guru dalam mengimplementasikan pembelajaran PAI pada Kurikulum 2013. Penelitian ini memberikan informasi hal-hal yang telah dan sedang dilakukan guru-guru PAI pada tingkat SMA di Aceh dalam upaya pengembangan kompetensi pedagogik.

\section{Metode}

Penelitian yang dilakukan adalah penelitian kualitatif Deskriptif, penelitian kualitatif merupakan penelitian yang dimaksudkan untuk memahami fenomena. Fenomena yang ada kemudian dibaca dari subyek penelitian yang memiliki ragam bentuk atribut. Atribut tersebut dapat berupa sikap, tindakan, persepsi, motivasi, yang dipersepsi secara holistic. Kemudian dilakukan deskripsi dalam bentuk kata-kata dan bahasa. Penelitian kualitatif memiliki landasan filsafat postpositivistik atau paradigma interpretive yaitu suatu realitas atau obyek yang tidak dapat dilihat secara parsial dan dipecah kedalam beberapa variabel [14]. Tujuan dari penelitian kualitatif deskriptif adalah untuk membuat deskripsi dengan karakter sistematis, faktual, dan akurat mengenai fakta dan sifat populasi atau daerah tertentu [15]. Peneliti memberikan perhatian kepada hal-hal yang nyata sebagaimana adanya di lapangan penelitian. Peneliti berusaha dengan daya dan kemampuannya memotret kejadian dan peristiwa yang terjadi.

Penelitian ini dilakukan di SMA Negeri 3 Langsa, SMA Negeri 1 Takengon, SMA Negeri 2 Mereubo, SMA Negeri 1 Peusangan Bireun, dan SMA Negeri 10 Fajar. Dari berbagai situs tersebut data dikumpulkan dengan teknik observasi, wawancara, dan dokumentasi. Observasi dilakukan oleh peneliti di sekolah tempat dilangsungkannya penelitian. Wawancara dilakukan oleh peneliti kepada guru-guru PAI, kepala sekolah, dan pihak-pihak yang terkait dalam bidang pendidikan. Adapun dokumentasi didapatkan oleh peneliti dari dokumen-dokumen yang dimiliki oleh informan.

Teknik analisis data menggunakan tahapan-tahapan pengumpulan data, pengelompokan data, reduksi data, dan pengambilan kesimpulan. Tahapan-tahapan ini dilakukan oleh peneliti pada saat melakukan penelitian, data-data tersebut divalidasi dengan informasi yang didapatkan dari data wawancara antara informan, dan bukti-bukti otentik dari dokumen dan observasi yang digunakan untuk memperkuat satu sama lain. 


\section{Hasil dan Pembahasan}

\subsection{Temuan Kompetensi Pedagogik Guru}

Profesi guru mengharuskan pendidik memiliki kompetensi-kompetensi sebagai bekal dalam mengoptimalkan proses belajar dan mengajar. Mulyasa mengutip pendapat Broke dan Stune menyatakan bahwa kompetensi guru adalah "...deskripsi sifat kualitatif prilaku guru yang nampak dan bermakna". Charles menyatakan "kompetensi merupakan kinerja rasional yang secara memuaskan memenuhi tujuan untuk kondisi yang diinginkan"[16]. Keberadaan kompetensi menjadi suatu keharusan untuk dimiliki dan dipraktekkan dalam proses pembelajaran. Dengan kompetensi, guru dianggap ahli dan mahir dalam menyelenggarakan dan melangsungkan proses belajar.

Adapun kompetensi pedagogik diungkapkan Muchith yaitu seperangkat kemampuan dan ketrampilan (skill) yang dimiliki oleh guru dalam hal interaksi belajar mengajar di dalam kelas. Kompetensi pedagogik mencakup kemampuan guru dalam menerangkan materi, pelaksanaan pembelajaran berbasis metode, keterampilan memberikan pertanyaan dan jawaban, penerimaan jawaban, pengelolaan kelas, dan tindakan evaluasi [17]. Habibullah (2012) mensyaratkan kompetensi pedagogik yang lazim dimilik oleh guru; a) memiliki pengetahuan tentang karakteristik siswa dalam berbagai aspek seperti aspek fisik, moral, spiritual, sosial, kultural, emosional, dan intelektual; b) memiliki pengetahuan dan kemampuan tentang teori belajar dan prinsip-prinsip pembelajaran; c) memiliki kemampuan pengembangan kurikulum yang sesuai dengan mata pelajaran yang diampu; d) mampu melaksanakan pembelajaran; e) memapu memberdayakan teknologi informasi dan komunikasi untuk proses pembelajaran; f) menyediakan sumber daya untuk pengembangan potensi siswa agar mengaktualisasikan potensi yang dimiliki; g) memiliki kemampuan komunikatif yang efektif, efektif, empatik, dan santun; h) melakukan penilaian, evaluasi proses dan hasil belajar; i) dapat mengambil umpan balik dari hasil penilaian dan evaluasi untuk kepentingan pembelajaran; dan j) mampu melakukan tindakan reflektif sebagai upaya untuk mengembangka kualitas pembelajaran [10].

Undang-Undang Nomor 14 Tahun 2005 Tentang Guru dan Dosen, pasal 1 ayat 10, disebutkan bahwa kompetensi adalah seperangkat pengetahuan, ketrampilan, dan perilaku yang harus dimiliki, dihayati, dan dikuasai oleh guru atau dosen dalam melaksanakan tugas keprofesionalan. Kemudian pada pasal 8 dijelaskan bahwa syarat wajib seorang guru adalah memiliki kualifikasi akademik, kompetensi, sertifikasi sehat jasmani dan rohani, serta memiliki kemampuan untuk mewujudkan tujuan pendidikan nasional. Pasal-pasal tersebut diperjelas dengan Peraturan Pemerintah Republik Indonesia Nomor 19 Tahun 2005 tentang Standar Nasional Pendidikan, pasal 28 menyebutkan yang dimaksud kompetensi pedagogik adalah kemampuan mengelola pembelajaran peserta didik yang meliputi pemahaman terhadap peserta didik, perencanaan dan pelaksanaan pembelajaran, evaluasi hasil belajar, dan pengembangan peserta didik untuk mengaktualisasikan berbagai potensi yang dimilikinya. Demikian itu dikuatkan dalam Standar Nasional Pendidikan pasal 28 ayat 3 butir a, dikemukakan bahwa kompetensi pedagogik adalah: Kemampuan mengelola pembelajaran peserta didik yang meliputi pemahaman terhadap peserta didik, perencanaan dan pelaksanaan pembelajaran, evaluasi hasil belajar, dan pengembangan peserta didik untuk mengaktualisasikan berbagai potensi yang dimilikinya.

Yasin (2011) mengungkapkan temuan pola pengembangan kompetensi pedagogik guru PAI di madrasah yaitu melalui tahapan-tahapan; a) Penyusunan perencanaan pengembangan berdasarkan pada hasil evaluasi diri kemampuan guru; b) Pelaksanaan pengembangan kompetensi melalui berbagai kegiatan pelatihan, workshop, deseminasi, fokus group diskusi, lokakarya, mendatangkan nara sumber yang ahli dengan bidangnya, pertemuan bersama guru secara rutin dan terstruktur, melakukan Penelitian Tindakan Kelas (PTK), dan meningkatkan pendidikan ke jenjang yang lebih tinggi; dan c) Keterlibatan pemerintah, madrasah, dan pendidik untuk meningkatkan dan mengembangkan kompetensi pedagogik [18].

Kompetensi pedagogik mutlak dimiliki dan dikuasai oleh para pendidik, kemampuan pendidik dalam mengelola pembelajaran bagi siswa yang efektif, efisien, sitematis, dan logis merupakan refleksi dari kompetensi yang dimiliki. Sebagai suatu profesi, kompetensi ini menentukan tingkat keberhasilan proses pembelajaran. Metode pembelajaran yang tepat, kesesuian bahan ajar dengan kurikulum yang diinstruksikan, pengetahuan terhadap kemampuan dan karakter siswa yang 
komprehensif dapat membantu proses pencapaian tujuan pembelajaran. Demikian itu sangat membutuhkan dukungan kompetensi pedagogik.

Tujuan pembelajaran dapat dicapai dengan metode yang tepat, bahan ajar yang sesuai, pengetahuan terhadap kemampuan dan karakter siswa yang komprehensif dapat dioptimalkan dengan kompetensi pedagogik.

Perspektif pendidikan Islam, Ibnu Khaldun menggunakan istilah malakah yang memiliki pengertian sangat luas apabila dibandingkan dengan teori insight dari Kohler. Insight memiliki kecenderungan penguasaan materi yang bersifat kognitif, sementara konsep malakah tidak membatasi cakupan pada domain pengetahuan atau kognitif, tetapi juga pada domain afektif dan psikomotorik. Malakah di sini dimaksudkan adalah malakah iman, malakah ilmu dan malakah sina'ah. Teori ini didukung dengan teori pembelajaran gradual yaitu suatu metode pembelajaran yang dilakukan secara bertahap, teori ini dinamakan dengan teori tadrij yang secara bahasa memiliki makna kebertahapan. Teori ini memiliki suatu karakter pembelajaran yang efektif mengharuskan suatu cara pembelajaran yang bertahap dan bertingkat. Implikasi dari teori ini adalah bahwa pembelajaran yang efektif dilakukan dengan penjelasan secara umum atau mujmalan, kemudian diikuti dengan penjelasan dan pengembangan atau syarh wa al-bayan, dan kemudian diakhiri dengan mengambil kesimpulan atau at-takhllus. Dengan demikian kurikulum yang disusun diharapkan memiliki prinsip keseimbangan, keberlanjutan, menyeluruh, keseimbangan, dan berintegritas.

bahwa belajar yang efektif dilakukan secara bertahap (gradual) sedikit demi sedikit dan berkelanjutan. Implikasi pedagogik dari teori ini adalah penstrukturan pengajaran dalam tiga tahapan, yaitu tahap ijmal (penyajian global), syarh wa al-bayan (pengembangan) dan takhallus (menyimpulkan-meringkaskan). Implikasi pedagogik terhadap kurikulum adalah bahwa penyusunan kurikulum harus dilandasi pada prinsip integritas (al-takamul), keseimbangan (al-tawazun), menyeluruh (al-syumul), kontinutas (al-ittisal) dan efisiensi (al-kifa'ah).

Model pendidikan Islam yang demikian itu memberikan suatu pemahaman pada urgensi keimanan dan tauhid sebagai landasan yang original dan menyeluruh dalam diri siswa. Dengan keimanan dan keyakinan Tauhid yang dimanifestasikan dalam kehidupan sehari-hari, siswa memiliki tujuan hidup yang jelas terkait asal dan kemana arah pendidikan diselenggarakan. Dasar ini memberikan pondasi dalam membangun program dan kegiatan sebagai sarana pendidikan. Pendidikan tidak saja mengembangkan kemampuan kognitif, tetapi juga mengembangkan aspek psikomotorik, yang didasari dengan nilai-nilai keimanan. Dua aspek ini diinternalisasikan dalam pembelajaran dengan ragam jenisnya, yang memotivasi guru dan siswa untuk tidak saja meningkat malakah keilmuannya, tetapi jua meningkat pada malakah sina'ah. Menjadi suatu keharusan peningkatan keilmuan, berimbang dengan peningkatan keyakinan dan budi pekertinya.

Berdasarkan observasi dan wawancara kepada guru SMA Negeri di Aceh ditemukan bahwa kompetensi pedagogik guru terdiri dari delapan kemampuan yaitu; 1) Guru-guru memiliki pemahaman dan wawasan tentang kependidikan; 2) Guru-guru memiliki pengetahuan dan pemahaman terhadap karakter siswa; 3) Guru-guru turut mendorong kepada para peserta didik untuk mengembangkan potensi dan bakat yang dimiliki; 4) Guru-guru turut bekerjasama dalam mengembangkan kurikulum dan silabus pembelajaran; 5) Guru-guru membuat perancangan pembelajaran; 6) Dalam pelaksanaan pembelajaran guru mendidik dengan penuh perhatian dan mengutamakan pendekatan dialogis; 7) Guru-guru turut memanfaatkan sarana teknologi pembelajaran; 8) Evaluasi pembelajaran dilakukan oleh guru-guru dengan baik.

Indikator kompetensi pedagogik tenaga pendidik SMA Negeri sangat baik, observasi yang dilakukan oleh peneliti dan pengumpulan bukti-bukti dokumentasi dari para guru di sekolah. Demikian itu dibuktikan dari keterlaksanaan proses pembelajaran dari perencanaan hingga evaluasi. Perencanaan pembelajaran dilakukan dengan membuat Rencana Program Pembelajaran (RPP) setiap akan melakukan proses pembelajaran. Selain daripada itu, para guru PAI membuat jadwal kegiatan tahunan dan semester dalam daftar tabel Program Tahunan (Prota), dan Program Semester (Promes). Pada pelaksanaan kegiatan pembelajaran, guru PAI memanfaatkan beragam metode dalam satu waktu pembahasan. Metode ceramah dipilih untuk dimanfaatkan memberikan penjelasan hal-hal yang belum banyak diketahui oleh siswa atau pengetahuan yang baru. Metode tanya-jawab digunakan pada saat penjelasan berlangsung untuk menstimuli pengetahuan siswa. Metode diskusi 
dilakukan pada saat mengharap keterlibatan siswa dalam pembelajaran. Kelompok belajar digunakan sebagai metode belajar yang efektif untuk saling berbagi pemahaman dan pengetahuan bersama. Pada proses pembelajaran tersebut guru-guru memanfaatkan sarana atau media pembelajaran yang dimiliki oleh sekolah yaitu komputer, In Focus, dan bahan ajar yang disampaikan melalui aplikasi software yang memudahkan proses pemahaman siswa. Pada akhir pembelajaran, guru-guru PAI melakukan evaluasi pembelajaran dengan memberikan pertanyaan secara langsung kepada siswa untuk mengukur ketercapaian tujuan pembelajaran. Lembar Kerja Siswa (LKS) diinstruksikan untuk dijawab oleh siswa. Pada pencapaian bab-bab yang telah ditentukan, guru PAI melakukan ulangan formatif secara harian, menyelenggarakan ujian tengah semester, dan melaksanakan ujian akhir semester. Berbagai kegiatan tersebut dilaksanakan dengan analisis mendalam terkait silabus pembelajaran dan waktu yang disediakan.

Demikian itu selaras dengan temuan Mulyadi (2011) pada penelitian kuantitatif yang menjelaskan proposisi temuan kompetensi pedagogik berdampak secara signifikan terhadap kinerja guru. Kemudian menyarankan untuk memberikan pelatihan peningkatan kompetensi pedagogik kepada guru PAI.[4] Munajat (2016) mengungkapkan temuan bahwa kegiatan PLPG yang diikuti oleh guru PAI dalam hal kompetensi pedagogik mendapatkan hasil yang baik yaitu $71 \%$, sementara nilai minimum yang didapatkan adalah $65 \%[11]$. PLPG berdampak memberikan kontribusi terhadap pengembangan kompetensi pedagogik.

\subsection{Upaya Peningkatan Kompetensi Pedagogik}

Secara prinsip pengembangan kompetensi telah dilakukan melalui proses pendidikan, pelatihan, dan berbagai aktifitas yang melibatkan guru. Pada aspek kegiatan pendidikan dan pelatihan adalah; a) pemberdayaan guru dalam berbagai aktifitas; b) kesempatan bagi guru untuk program magang; c) program kemitraan sekolah dengan lembaga lain; d) pembelajaran jarak jauh; e) pelatihan formal yang dilakukan secara berjenjang dan pelatihan formal untuk tujuan yang khusus; f) short course di perguruan tinggi atau lembaga pendidikan lainnya; g) pembinaan dan bimbingan secara internal; dan h) Pendidikan untuk jenjang yang lebih tinggi.

Adapun program yang diselenggarakan untuk mengembangkan kompetensi adalah; a) forum group diskusi terkait pendidikan dan pembelajaran; b) menyelenggarakan seminar yang mensertakan guru-guru; c) pelatihan dan implementasi hasil pelatihan; d) mendorong guru-guru untuk membuat penelitian tindakan kelas; e) pengembangan buku dan bahan ajar pembelajaran; f) pengembangan penggunaan media yang mendukung proses pembelajaran; dan g) menciptakan karya teknologi pembelajaran atau karya dalam bentuk seni yang bermanfaat.

Wawancara yang dilakukan kepada salah seorang guru PAI di SMA Negeri Langsa disampaikan upaya yang telah dilakukan kepala sekolah adalah mengikuti pertemuan MGMP PAI Kota Langsa yang diadakan setiap semester sekali, membaca buku-buku agama, mendengarkan ceramah-ceramah keagamaan yang berhubungan dengan PAI, mengikuti seminar, mengikuti kegiatan penataran yang diselenggarakan oleh Dinas Pendidikan dan Kementrian Agama Banda Aceh. Selain daripada itu, guru-guru mengikuti pelatihan kurikulum KTSP dan pelatihan kurikulum 2013 yang diadakan oleh Kemenag Provinsi Aceh (Wawancara Azmah Usmanuddin). Kepala Sekolah dan Wakil Kurikulum pada saat diambil datanya melalui metode wawancara mengungkapkan bahwa pengembangan kompetensi pedagogic dilakukan melalui supervisi pembelajaran, validasi perangkat mengajar, bimbingan dan evaluasi pada rapat guru, dorongan dan motivasi untuk mengembangkan diri dengan studi lanjut, mengirim guru untuk berpartisipasi pada kegiatan Diklat yang diselenggarakan oleh pemerintah atau swasta, berperan aktif dalam kegiatan MGMP, dan workshop. Semua guru diberikan kesempatan yang sama untuk melanjutkan pendidikan pada jenjang S2 (Wawancara Amir Hamzah). Demikian itu juga disampaikan oleh Kepala SMA Negeri 10 Banda Aceh yang menyampaikan hal yang sama yaitu keterlibatan dalam MGMP guru PAI, mengikuti seminar, workshop, pelatihan-pelatihan Kurikulum KTSP dan Kurikulum 2013 yang diselenggarakan oleh Kemenag ataupun Kemendiknas. Guru PAI juga sering mengikuti seminar di luar daerah seperti ke Jakarta, undangan seluruh ketua MGMP yang mewakili dari provinsi masing-masing, walaupun di saat dilakukan pelatihan dan seminar hanya dalam waktu yang singkat sehingga kurang efektif. Upaya lainnya adalah dengan membaca buku yang berkenaan dengan pendidikan agama Islam tidak hanya membaca buku pegangan guru saja (Wawancara Mustafa). Disampaikan juga oleh Zulkarnain dan Nuriati yaitu kepala sekolah dan wakil kurikulum yang mengungkapkan upaya yang dilakukan yaitu dengan menyelenggarakan rapat pembinaan mutu guru, saran dan motivasi untuk studi lanjut 
ke jenjang S2, mengikuti kegiatan yang diselenggarakan oleh MGMP, dan workshop pelatihan kemampuan guru PAI dalam penguasaan teknologi komputer (Wawancara Zulkarnain dan Nuriati).

Wawancara juga dilakukan dengan Kepala Sekolah SMA Negeri 1 Peusangan Bireuen yang menyebutkan bahwa hal-hal yang dilakukan sebagai upaya mengembangkan kompetensi pedagogic adalah dengan mengembangkan kreatifitas dan inovasi baik dari segi seni maupun teknologi. Guruguru didorong untuk membuat karya yang berkontribusi positif terhadap pengembangan masyarakat. Karya tersebut bisa dibuat dalam bentuk produk pendidikan atau juga karya dalam bentuk seni yang mengandung unsur keindahan yang mendapatkan pengakuan dari warga masyarakat. (Wawancara Akmal).

Data yang demikian beragam itu dapat dipahami upaya peningkatan kompetensi pedagogik guru di lokasi penelitian adalah; 1) guru-guru mengikuti kegiatan pelatihan dan pengembangan kurikulum dan teknologi pembelajaran yang diselenggarakan oleh MGMP, Kemenag, dan Kemendiknas ; 2) guru-guru membaca referensi buku-buku agama Islam selain buku pedoman guru dan buku bahan ajar bagi murid; 3) kepala sekolah menyelenggarakan proses supervisi pembelajaran PAI; 4) kepala sekolah memotivasi dan mendorong guru-guru untuk meningkatkan diri melalu proses pembelajaran pada tingkat yang lebih tinggi; dan 5) kepala sekolah memberikan saran dan masukan pembinaan mutu guru dalam pembelajaran. Berbagai upaya tersebut dilakukan oleh oleh guru-guru, kepala sekolah, dan pemerintah secara konsisten dan berkelanjutan.

Data tersebut menginformasikan suatu proses pengembangan sumber daya manusia yang dilaksanakan dengan kesadaran dan keterlibatan partisipatif guru PAI, pengelola sekolah yang terdiri dari kepala sekolah, pemerintah - Kemenag dan Kemendiknas. Upaya-upaya tersebut diselenggarakan diikuti dengan baik oleh guru-guru, hasil yang didapatkan adalah meningkatnya proses pembelajaran yang baik dan memberikan jawabat terhadap permasalahan yang dihadapai oleh guru pada proses pembelajaran. Sehingga mutu dan kualitas pembelajaran yang didapatkan oleh peserta didik berkembang dengan baik.

Temuan bahwa upaya peningkatan kompetensi pedagogik guru yang dilakukan melalaui MGMP adalah juga selaras dengan temuan yang disampaikan oleh Gani (2014) yang mengungkapkan peran kelompok kerja guru PAI yang signifikan terhadap peningkatan kompetensi pedagogik guru [19]. Demikian itu ditunjukkan dengan pelaksanaan pembelajaran yang berpedoman pada perencanaan pembelajaran yang telah dissuu, proses penilaian yang baik dengan sistematis, dan analisis hasil belajar.

Sebagaimana temuan yang disampaikan Zulvah (2013) bahwa upaya peningkatan kompetensi pedagogik dapat dilakukan dengan memperkaya referensi guru-guru dalam hal bacaan yang berisi tentang pengembangan kompetensi pedagogik, mengikuti kegiatan pelatihan dan pengembangan, melakukan refleksi pembelajaran, memeriksa proses dan hasil pembelajaran, menyelenggarakan kegiatan supervisi pembelajaran, dan memberikan penugasan kepada para guru agar mengikuti seminar pendidikan dan melakukan pengambangan diri [20]. Umami dan Roesminingsih (2014) mengemukakan bahwa kepala sekolah selaku pengambil kebijakan memiliki fungsi yang penting dalam upaya peningkatan pengetahuan, kemampuan, dan kompetensi pedagogik guru. Upaya tersebut dapat dilakukan melalaui kegiatan pendidikan dan pelatihan yang dilakukan berdasarkan keterlibatan dalam program supervisi dan berperan aktif mendampingi proses peningkatan kompetensi pedagogic [7]. Senada dengan hal tersebut disampaikan Ginanjar dan As-Surur (2018) yang mengemukakan bahwa pola kepemimpinan memberikan pengaruh terhadap kompetensi pedagogik guru PAI [21].

Ismail (2015) mengungkapkan bahwa pada prinsipnya guru sebagai tenaga pendidik telah memiliki pengetahuan tentang landasan kependidikan yang didapatkan saat guru tersebut mengenyam pendidikan di perguruan tinggi. Namun dengan kondisi peserta didik yang berkembang dan perkembangan ilmu pengetahuan, guru sangat berkebutuhan untuk mengembangkan diri untuk memperluas pemikiran dan mampu menyerap perkembangan masyarakat. Pendidikan dan pelatihan menjadi kebutuhan yang mendasar bagi peningkatan kompetensi pedagogic guru PAI, agar mampu mengembangka pengajaran agama Islam secara holistik [3]. Senada dengan hal tersebut, Mulyadi (2011) yang menyimpulkan suatu temuan bahwa kompetensi pedagogik berpengaruh terhadap kinerja guru menyarankan untuk menyelenggarakan pelatihan bagi guru-guru PAI [4]. 
Rofi'ah (2014) memberikan solusi terhadap pengembangan kualitas kompetensi pedagogik dan peningkatannya yaitu melalui penerapan model pembelajaran koperatif bagi guru PAI. Kelebihan dari model pembelajaran ini adalah guru dapat memberdayakan berbagai teknik dan metode yang baik dan relevan, sehingga proses pembelajaran menjadi multi-arah, dan terjadi keragaman sumber belajar [22]. Pengembangan ini membutuhkan motivasi yang tinggi dari guru PAI dalam mengelola kelas agar peserta didik terpacu untuk berkolaborasi dengan guru dan bekerjasama dengan yang lain.

\subsection{Kendala Guru PAI dalam Implementasi Kurikulum}

Pada pembahasan ini yang dibahas adalah kendala guru dalam implementasi kurikulum, Suharizal kepala sekolah di SMA Negeri di Aceh mengungkapkan kendala yang dihadapi yaitu terkait motivasi guru, sebagian guru memiliki motivasi belajar yang rendah, lemahnya kemampuan dalam penguasaan teknologi informasi, malas untuk mengikuti kegiatan-kegiatan pengembangan, dan usia guru yang sudah lanjut sehingga sulit dalam mengikuti pembinaan dalam rangka peningkatan kompetensinya. Beberapa guru kurang bisa belum bisa memanfaatkan komputer dan infokus dalam proses pembelajaran (Wawancara Suharizal). Kendala yang ditemukan juga adalah guru merasa sulit dengan struktur kurikulum yang berubah-ubah sebagai akibat dari pergantian kurikulum yang ditetapkan yaitu kurikulum KTSP dan Kurikulum 2013. Kendala lain yaitu terkait evaluasi pembelajaran, yaitu terkait dengan format penilaian yang rumit, yang berimplikasi terhadap kegiatan evaluasi peserta didik bersamaan dengan proses pembelajaran yang demikian itu mengganggu penyampaian materi pembelajaran (Wawancara Raimatun). Wawancara dengan Azmah Usmanuddin mengungkapkan kendala yang dihadapi adalah kendala dalam pengembangan kurikulum yang disebabkan oleh keterbatasan waktu, perbedaan pendapat dalam pengembangan kurikulum antara guru PAI, kepala sekolah, dan adiministrator (Wawancara Azmah Usmanuddin). Kendala terkait sarana dan prasarana yaitu diungkapkan bahwa buku-buku referensi yang dibutuhkan sebagai bacaan untuk memperkaya pengetahuan dan wawasan yang mendukung pembelajaran PAI masih sangat minim, yang dibuktikan dengan minimnya buku-buku terkait keagamaan Islam, buku-buku terkaitu pendalaman Al-Qur'an termasuk tafsir dan ilmu-ilmunya, dan buku-buku Hadits dan ilmu-ilmunya, dan referensi tentang keagamaan. Halimah mengungkapkan kendala implementasi kurikulum yaitu keterbatasan jam pelajaran PAI yang terbatas dalam 2 jam memenuhi pelajaran-pelajaran Al-Qur'an dan Al-Hadits, Aqidah Akhlaq, Fiqh, dan Bahasa Arab. Semua itu telah ditetapkan pemerintah dalam struktur kurikulum, sehingga menjadi tanggungjawab guru PAI dalam membentuk kepribadian peserta didik (Wawancara Halimah).

Kendala implementasi kurikulum PAI yang dihadapi adalah; 1) Guru kurang motivasi untuk meningkatkan mutu pembelajaran yang telah dilakukan; 2) Kemampuan penguasaan teknologi dan informasi dalam menyelenggarakan pembelajaran yang rendah; 3) Perubahan kurikulum yang tidak diiringi dengan sosialisasi perubahan; 4) Perubahan proses evaluasi pembelajaran yang tidak diiringi dengan pelatihan penilaian pembelajaran; 5) Terbatasnya sumber belajar yang disediakan di perpustakaan sekolah; 6) Minimnya anggaran yang dialokasikan untuk pengembangan fasilitas atau saranan pembelajaran; 7) Alokasi struktur kurikulum pembelajaran yang terbatas; dan 8) Input peserta didik yang belum optimal untuk masuk jenjang pendidikan menengah.

Temuan tersebut senada dengan Munajat (2016) yang mengungkapkan kendala dalam implementasi Kurikulum 2013 yaitu sistem pembinaan dan pengembangan guru PAI yang minim, penggunaan teknologi dan informasi yang belum merata, dan keterbatasan dana yang berimplikasi pada kinerja KKG dan MGMP yang tidak optimal [11].

\section{Kesimpulan}

Guru-guru, kepala sekolah, pengawas dan pemerintah telah berupaya bersama-sama mengembangkan kompetensi pedagogik guru pendidikan agama Islam melalaui kegiatan pelatihan dan pengembangan, yaitu; 1) guru-guru mengikuti kegiatan pelatihan dan pengembangan kurikulum dan teknologi pembelajaran yang diselenggarakan oleh MGMP, Kemenag, dan Kemendiknas ; 2) guru-guru membaca referensi buku-buku agama Islam selain buku pedoman guru dan buku bahan ajar bagi murid; 3) kepala sekolah menyelenggarakan proses supervisi pembelajaran PAI; 4) kepala sekolah memotivasi dan mendorong tenaga pendidikan untuk mengembangkan pendidikannya pada jenjang yang lebih tinggi; dan 5) kepala sekolah memberikan saran dan masukan pembinaan mutu guru dalam pembelajaran. Berbagai 
upaya tersebut dilakukan oleh oleh guru-guru, kepala sekolah, dan pemerintah secara konsisten dan berkelanjutan.

Adapun kendala implementasi kurikulum berdasarkan kompetensi pedagogik yang dikembangkan oleh guru-guru adalah; 1) Guru kurang motivasi untuk meningkatkan mutu pembelajaran yang telah dilakukan; 2) Kemampuan penguasaan teknologi dan informasi dalam menyelenggarakan pembelajaran yang rendah; 3) Perubahan kurikulum yang tidak diiringi dengan sosialisasi perubahan; 4) Perubahan proses evaluasi pembelajaran yang tidak diiringi dengan pelatihan penilaian pembelajaran; 5) Terbatasnya sumber belajar yang disediakan di perpustakaan sekolah; 6) Minimnya anggaran yang dialokasikan untuk pengembangan fasilitas atau saranan pembelajaran; 7) Alokasi struktur kurikulum pembelajaran yang terbatas; dan 8) Input peserta didik yang belum optimal untuk masuk jenjang pendidikan menengah.

\section{Referensi}

[1] R. Idris, "Perubahan sosial budaya dan ekonomi Indonesia dan pengaruhnya terhadap pendidikan," Lentera Pendidik., vol. 14, no. 2, pp. 219-231, 2011.

[2] E. Mulyasa, Pengembangan Implementasi Kurikulum 2013. Bandung: Remaja Rosda Karya, 2014.

[3] I. Ismail, "Peningkatan Kompetensi Pedagogik Guru PAI dalam Pembelajaran," $J$. MUDARRISUNA Media Kaji. Pendidik. Agama Islam, vol. 4, no. 2, pp. 704-719, 2015.

[4] A. Mulyadi, "Kontribusi Kompetensi Pedagogik dan Iklim Organisasi terhadap Kinerja Guru," J. Turats, vol. 7, no. 2, pp. 49-61, 2011.

[5] A. Kosim, "Kompetensi Pedagogik Guru dan Mutu Pembelajaran Pendidikan Agama Islam," J. Madaniyah, vol. 2, no. 11, pp. 260-275, 2016.

[6] S. Indra, "Pengaruh Kompetensi Pedagogik dan Kompetensi Profesional Guru PAI terhadap Prestasi Belajar PAI Pada Siswa SMK Farmako Medika Plus Caringin Bogor,” 2016.

[7] D. R. Umami and E. Roesminingsih, "Pengaruh Kompetensi Pedagogik dan Motivasi Kerja Guru Terhadap Prestasi Belajar Siswa dalam Ujian Nasional (UN) di SMA Negeri Se Kota Mojokerto," J. Inspirasi Manaj. Pendidik., vol. 3, no. 3, pp. 81-88, 2014.

[8] A. Rizqi, A. Affandi, and M. Nuryadien, "PENGARUH KOMPETENSI PEDAGOGIK GURU PAI TERHADAP MOTIVASI BELAJAR SISWA SMP NEGERI 11 KOTA CIREBON," ITQAN, vol. 10, no. 2, pp. 109-119, 2019.

[9] H. T. Abdillah, "Pengaruh Kompetensi Profesional Dan Pedagogik Guru," J. Pendidik. Ilmu Sos., vol. 24, no. 2, pp. 145-151, 2015.

[10] A. Habibullah, "Kompetensi Pedagogik Guru," EDUKASI J. Penelit. Pendidik. Agama dan Keagamaan, vol. 10, no. 3, pp. 362-377, 2012.

[11] N. Munajat, "Kompetensi Pedagogik Guru Dalam Pembelajaran PAI Sesuai Kurikulum 2013 Pada Kegiatan PLPG Di FITK UIN Sunan Kalijaga," J. Pendidik. Agama Islam, vol. 13, no. 2, pp. 211-221, 2016.

[12] E. Mulyasa, Menjadi Guru Propesional Menciptakan Pembelajaran Kreatif dan Menyenangkan. Bandung: Remaja Rosda Karya, 2005.

[13] M. Hambali, "Manajemen Pengembangan Kompetensi Guru PAI," J-MPI (Jurnal Manaj. Pendidik. Islam., vol. 1, no. 1, pp. 70-89, 2016.

[14] Sugiyono, Metode Penelitian Kuantitatif, Kualitatif dan $R \& D$. Bandung: Alfabeta, 2008.

[15] E. Emzir, Metodologi Penelitian Pendidikan Kuantitatif dan Kualitatif. Jakarta: Rajawali Press, 2013.

[16] E. Mulyasa, Standar Kompetensi Sertifikasi Guru. Bandung: Remaja Rosda Karya, 2007. 
[17] M. S. Muchith, Pembelajaran Kontekstual. Semarang: Rasail Media, 2008.

[18] A. F. Yasin, "Pengembangan Kompetensi Pedagogik Guru Pendidikan Agama Islam di Madrasah (Studi Kasus di MIN Malang I)," El-Qudwah, vol. 1, no. 5, pp. 157-181, 2011.

[19] A. Gani, "Peran Kelompok Kerja Guru Pendidikan Agama Islam dalam Meningkatkan Kompetensi Pedagogik Guru di Sekolah Dasar Negeri Gugus Kecamatan Payaraman Kabupaten Ogan Ilir," Conciencia, vol. 14, no. 1, pp. 1-21, 2014.

[20] I. Zulvah, "Kompetensi Pedagogik Guru Pendidikan Agama Islam Sekolah Menengah Atas," MUDARRISA J. Kaji. Pendidik. Islam, vol. 5, no. 2, pp. 270-298, 2013.

[21] M. Hi. Ginanjar and M. As-Surur, "Kepemimpinan Kepala Sekolah dan Pengaruhnya Terhadap Peningkatan Pedagogik Guru Pendidikan Agama Islam di SMP Negeri 3 Karawang Jawa Barat," Islam. Manag., vol. I, no. 2, pp. 207-232, 2018.

[22] N. H. Rofiah, "Mengembangkan Kompetensi Pedagogik Guru Pai Sd / Mi Dengan Model Pembelajaran Kooperatif," J. Pendidik. Dasar Din., vol. 6, no. 2, pp. 246-262, 2014. 